УДК 574.44:57.087.2

\author{
В. В. Бригадиренко, О. С. Комаров
}

Дніпропетровський національний університет ім. Олеся Гончара

\title{
ТРОФІЧНА СТРУКТУРА ПІДСТИЛКОВОЇ МЕЗОФАУНИ: РОЗПОДІЛ БІОМАСИ ЗА ТРОФІЧНИМИ РІВНЯМИ
}

На основі досліджень підстилкової мезофауни чотирьох лісових біогеоценозів Полтавської області побудовано трофічно-вагові моделі угруповань безхребетних. Проаналізовано розподіл біомаси за трофічними рівнями, розмірну і таксономічну структуру окремих рівнів. Охарактеризовано відмінності та спільні риси трофічно-вагових моделей угруповань безхребетних.

$$
\begin{gathered}
\text { V. V. Brygadyrenko, O. S. Komarov } \\
\text { Oles' Gonchar Dnipropetrovsk National University }
\end{gathered}
$$

\section{TROPHIC STRUCTURE OF LITTER MESOFAUNA: BIOMASS DIFFERENTIATION BETWEEN TROPHIC LEVELS}

On the basis of research of litter mesofauna in four forest biogeocenoses of the Poltava region the trophic-weight models of invertebrate communities are creating. The biomass differentiation between trophic levels, weight and taxonomic structure of the separate levels are analysed. The differentiation and similarity of the trophic-weight models of litter invertebrate communities are discussed.

\section{Вступ}

Тваринне населення лісового біогеоценозу об'єднує велику кількість різноманітних організмів, які перебувають у постійних складних взаємовідносинах. Одними 3 найважливіших типів зв'язків виступають трофічні. Останні, разом із топічними та фабричними, утворюють консорції - елементарну частину біогеоценозу [12]. Поняття про консорції запропоноване Л. Г. Раменським [24] та В. Н. Беклемішевим [2]. Вони дали визначення консортів і привернули велику увагу до їх дослідження. В. В. Мазінг [17] визначає консорцію як сукупність усіх організмів, пов'язаних у своїй життєдіяльності з визначеним видом автотрофа. Цей автор підкреслює, що можна розуміти під консорцією сукупність організмів, поєднаних із групою близьких видів рослин.

В. В. Мазінг розширює ємність поняття консорції, включає до неї інші види трофічних ланцюгів, пов'язані з продуцентом через споживачів первинної продукції [17]. В. І. Василевич [10] у своій праці «Очерки теоретической фитоценологии» пише: «Не следует также ограничивать центры консорций лишь автотрофными высшими растениями. Это, по-моему, узкоботанический взгляд на общебиологическое явление. Консорции, образованные животными, очень сходны по структуре с консорциями растений. Разные термины для тех и других не нужны».

Слід зосередити увагу на принципово різних відносинах, що лежать в основі консортивних зв'язків і трофічних ланцюгів. Як зазначає В. І. Василевич [10], консортивні зв'язки виникають у тому випадку, коли існують безпосередні трофічні зв'язки з конкретною особиною виду. При цьому особини двох видів повинні бути настільки

(C) В. В. Бригадиренко, О. С. Комаров, 2008 
тісно пов'язані між собою, що організм, який живиться, безпосередньо залежить від долі організму, що $є$ трофічним об'єктом. В основі ланцюгів живлення головну роль відіграють відносини «хижак - жертва» [21]. Зв'язки утворюються не на організменому рівні, а на популяційному [25]. Таким чином, ланцюг живлення охоплює особини 3 першого трофічного рівня до останнього.

Т. А. Работнов [19; 20] до складу консорцій включає і редуцентів. Не можна не відзначити великий внесок у розробку вчення про консорцію Б. А. Бикова [9], Н. В. Диліса [12], І. А. Селіванова [27]. Вони вважають, що центрами консорцій можуть виступати гетеротрофні організми. Потім із цією концепцією погодився Т. А. Работнов [22; 23], який вважав такий підхід правильним, тому що він зберігає за консорцією загальноекологічний зміст.

Вчення про біогеоценоз В. М. Сукачова [30-32], основи степового лісівництва О. Л. Бельгарда [3], генезу лісових грунтів у Степу А. П. Травлєєва [34] значною мірою базуються на дослідженнях функціонального впливу тварин на інші компоненти біогеоценозу. Роботи М. С. Гілярова [11], С. В. Зонна [14] вказують, що наземна та грунтова фауна відіграє значну роль у кругообігу речовин шляхом трансформації грунту та лісової підстилки. У природних умовах інтенсивність розкладу опаду та підстилки коливається у значних межах під дією різних факторів, одним з яких є вплив безхребетних тварин. Герпетобій має складну функціональну структуру. Сапрофаги, що зазвичай домінують у підстилковому біогеогоризонті $[1 ; 15 ; 16 ; 33-35]$, роблять суттєвий внесок у розклад підстилки $[26 ; 28 ; 29 ; 37 ; 39 ; 40]$. Проте чисельність як сапрофагів, так і фітофагів безпосередньо та опосередковано регулюється хижими та паразитичними видами безхребетних (турунами, стафілінами, павуками, паразитичними перетинчастокрилими тощо).

Таким чином, середовищетвірна активність тварин виступає одним із найважливіших екологічних чинників у формуванні лісових біогеоценозів [6-8]. Це забезпечує зростання їх біорізноманіття [13] та екологічної стійкості до антропогенного тиску. Оцінка ролі безхребетних у формуванні такого важливого компонента лісу, як підстилка, повинна стати обов'язковою частиною системи заходів з охорони навколишнього середовища та збереження існуючих лісових угруповань.

Система графічного подання трофо-консортивних зв'язків з урахуванням розмірів і чисельності організмів, запропонована у наших попередніх дослідженнях [4; 5], дозволяє наочно уявити складність і різноманітність угруповань безхребетних тварин.

Мета даної роботи - проаналізувати трофічну структуру підстилкової мезофауни окремих типів лісу з урахуванням розмірно-вагових особливостей і рухової активності безхребетних тварин на прикладі лісових біогеоценозів Полтавської області.

\section{Матеріал і методи досліджень}

Для відображення структури герпетобію та полегшення розуміння трофічної структури окремих біогеоценозів нами запропоновано використовувати просторовофункціонально-розмірні моделі [4]. Для окремого біогеогоризонту (наприклад підстилки) модель будується у двовимірній системі координат. Шкала осі абсцис відображає середню суху вагу тіла тварини. Окремі трофічні рівні на осі ординат відокремлені: знизу розташовані фітофаги та сапрофаги (включаючи фітосапрофагів, копрофагів і некрофагів), над ними - зоофаги I, II та III порядків (включаючи паразитів та пантофагів).

Таким чином на моделі схематично показано розташування тварин в окремо взятому біогеоценозі залежно від їх ваги та трофічної спеціалізації. На одній моделі розміщено безхребетних, зібраних різними методами. Для відображення трофічної та роз- 
мірної структури герпетобію використано метод ручного розбирання підстилки, що дозволяє оцінити абсолютну чисельність і біомасу підстилкових безхребетних на площі $1 \mathrm{~m}^{2}$. Біомаса популяції тварин, зібраних цим методом, відображається безперервним колом, діаметр якого відповідає біомасі популяції (рис. 1-4). Кола, позначені пунктиром, відображають популяції безхребетних, які потрапили до пасток Барбера, але не були зібрані за допомогою методу ручного розбирання підстилки. Лише грунтовими пастками враховуються види 3 підвищеною руховою активністю та низькою абсолютною чисельністю (більшість видів зоофагів I-III порядку). Ці таксони можуть істотно впливати на функціонування герпетобію, виступаючи регуляторами чисельності домінантних за біомасою видів.

В основу роботи покладено дослідження підстилкової мезофауни, виконані в межах південної частини лісостепової зони (Полтавська область, Кременчуцький та Козельщанський райони), які проводили протягом літнього сезону 2006 року. Обстежено чотири пробні ділянки, що належать до поширених типів дібров заплави ріки Псел. Збирали підстилкових безхребетних із застосуванням пасток Барбера (як пастки використовували поліпропіленові стаканчики, фіксатор - 20 \% розчин $\mathrm{NaCl}$ ). На кожній пробній ділянці одночасно функціонувало 10 пасток, вибірки проводили через 5 діб. Крім цього застосовували метод ручного розбирання підстилки (проби площею $0,25 \mathrm{~m}^{2}$ ). Середню суху вагу зібраних тварин визначали на торсійних вагах ВТ-500 із точністю до 0,5 мг (для 10-20 особин кожного виду). Для переведення живої ваги на повітряно-суху застосовано розрахунки, виконані Ю. І. Черновим та співавторами [38].

Пробна ділянка 1. Dc' $2-3$ - гігромезофільна липова діброва із широкотрав'ям. Зімкненість крон деревостану складає - 90 \% (дуб звичайний Quercus robur L. - $40 \%$, липа серцелиста Tillia cordata Mill. - 30\%, в'яз гладенький Ulmus laevis Pall. - 10 \%, клен гостролистий Acer platanoides L. - 5 \%, клен татарський Acer tataricum L. - 5 \%). Чагарниковий ярус не представлений. Трав'яний ярус - $25 \%$ (купина багатоквіткова Polygonatum multiflorum (L.) All. - 10 \%, яглиця звичайна Aegopodium podagraria L. $10 \%$, фіалка Viola sp. - 5 \%). Підстилка двошарова, суцільна, легко відокремлюється від грунту, співвідношення між шарами 2:1 (без чіткого поділу), потужність не перевищує 4 см. Верхній шар пухкий, із цілим листям. Нижній шар трухоподібний, добре виражений, легко відокремлюється від грунту.

Пробна ділянка 2. $D c^{\prime}{ }_{3}$ - мезогігрофільна діброва 3 конвалією. Зімкненість крон деревостану складає 80 \% (домінує дуб звичайний Quercus robur L.). Чагарниковий ярус має проективне покриття $25 \%$ (жостір проносний Rhamnus cathartica L. $-15 \%$, ожина сиза Rubus caesius L. - $10 \%$ ). Проективне покриття трав'яного ярусу $-35 \%$ (конвалія звичайна Convallaria majalis L. - 30\%, хвилівник звичайний Aristolochia clematitis L. - 5 \%). Підстилка двошарова, суцільна, легко відокремлюється від грунту, співвідношення між шарами 1:2, потужність - 4 см. Верхній шар пухкий, грудкуватої структури з цілим і напіврозкладеним листям, нижній - добре виражений, трухоподібний, розсипчастий.

Пробна ділянка 3. Dac' ${ }_{3}$ - мезогігрофільна липо-ясенева діброва із широкотрав'ям. Зімкненість крон деревостану складає - $80 \%$ (ясен звичайний Fraxinus excelsior L. - 50\%, дуб звичайний Quercus robur L. - 10\%, липа серцелиста Tillia cordata Mill. - $10 \%$, клен звичайний Acer platanoides L. - $10 \%$ ). Чагарниковий ярус не виражений. Трав'яний ярус - 70 \% (яглиця звичайна Aegopodium podagraria L. $-40 \%$, купина багатоквіткова Polygonatum multiflorum (L.) All. - 15 \%, бугила лісова Anthriscus sylvestris (L.) Hoffm. - $5 \%$, кропива дводомна Urtica dioica L. $-5 \%$, конвалія звичайна Convallaria majalis L. - 5 \%). Підстилка двошарова, потужність 2,5 см, суцільна, погано 
відокремлюється від грунту, з міцелієм гриба. Співвідношення між шарами 1:2. Верхній шар щільний, погано відокремлюється від нижнього; нижній - добре виражений, трухоподібний.

Пробна ділянка 4. $\mathrm{Dn}{ }_{3}$ - мезогігрофільна в'язо-ясенева діброва із широкотрав'ям. Зімкненість крон деревостану складає 60 \% (в'яз гладенький Ulmus laevis Pall. $25 \%$, ясен звичайний Fraxinus excelsior L. - $25 \%$, дуб звичайний Quercus robur L. $5 \%$, клен ясенолистий Acer negundo L. - $5 \%$ ). Чагарниковий ярус має проективне покриття - $30 \%$ (ожина сиза Rubus caesius L.), трав'яний ярус - 60 \% (яглиця звичайна Aegopodium podagraria L. - 30 \%, підмаренник чіпкий Galium aparine L. - 15 \%, бугила лісова Anthriscus sylvestris (L.) Hoffm. - 5 \%, кропива дводомна Urtica dioica L. - 5 \%, кропива глуха пурпурова Lamium purpureum L. - 5 \%). Підстилка переривчаста, двошарова, співвідношення між шарами 2:1, потужність не перевищує 1,5 см. Верхній шар пухкий, розсипчастий, погано відокремлюється від нижнього; нижній шар має слабку трухоподібну структуру, легко відокремлюється від грунту.

\section{Результати та їх обговорення}

Гігромезофільні липові діброви із широкотрав'ям - поширені типи лісу у Полтавській області. Мезофауна цього типу лісу (рис. 1, табл.) представлена всіма функціональними групами безхребетних. Сапрофаги (58,1 \% за чисельністю) та фітофаги (6\%) домінують у герпетобії. Розташування популяцій на трофічно-ваговій моделі підстилкової мезофауни характеризується високою кількістю видів фітофагів і сапрофагів і майже рівномірним їх розподілом за вагою (від 1 до 128 мг).

На другому трофічному рівні знаходяться хижі тварини, яких віднесено до зоофагів першого порядку (ї чисельність - 0,6 \% від загальної). Переважна більшість тварин, що належать до цього трофічного рівня, має суху вагу близько 1-4 мг. Відносно малі розміри - причина того, що ці тварини можуть виступати не тільки як хижаки, що живляться безхребетними нижчого порядку, а й як об'єкти живлення зоофагів вищих трофічних рівнів. Наприклад Lithobiidae sp. належить до другого трофічного рівня; проте серед тварин, які входять до потенційних жертв цього виду, можуть траплятися інші безхребетні другого рівня. Оскільки Lithobiidae sp. мають невелику середню вагу (2 мг), вид потрапляє до раціону зоофагів II порядку, наприклад турунів, що підтверджено результатами власних лабораторних спостережень.

Сумарна чисельність зоофагів II порядку - 3,4 \% чисельності герпетобію. Тут перебувають більші за розмірами організми (порівняно з попереднім рівнем), проте вони можуть входити до раціону зоофагів вищих трофічних рівнів (представлених хребетними тваринами) - представників інших біогеогоризонтів лісової екосистеми. Наприклад Philonthus fumarius Graw., Ph. decorus Graw. та Ph. sp. за результатами лабораторних спостережень поїдаються турунами роду Carabus. Поряд із хижаками до цього рівня віднесено паразитичних комах, наприклад види родини Ichneumonidae.

До четвертого трофічного рівня віднесено пантофагів і зоофагів III порядку. Чисельність цього трофічного рівня становить 30,9 \% від загальної чисельності мезофауни. Великі за розмірами туруни (наприклад Carabus marginalis Fabricius, 1794) не можуть виступати об'єктами живлення інших безхребетних лісових екосистем. Великі комахи активно поїдаються амфібіями, рептиліями, комахоїдними птахами та ссавцями. До пантофагів належать мурахи, які виступають не тільки активними зоофагами, а і збирають виділення попелиць, нектар та насіння рослин. Вони можуть також паразитувати у гніздах інших інших перетинчастокрилих, збирати загиблих безхребетних, 
живитися трупами тощо. Нерівномірний розподіл біомаси на різних трофічних рівнях може свідчити про порушеність екологічного балансу у герпетобії цієї пробної площі.

Таблиия

Трофічно-вагова структура (мг/м² сухої ваги)

підстилкової мезофауни лісових біогеоценозів Полтавсыкої області

\begin{tabular}{|c|c|c|c|c|c|c|}
\hline \multirow{2}{*}{ Пробна ділянка } & \multirow{2}{*}{ Трофічна група } & \multicolumn{4}{|c|}{ Вагова група, мг сухої ваги } & \multirow{2}{*}{ Разом } \\
\hline & & $0,5-3,9$ & $4,0-15,9$ & $16,0-63,9$ & $64,0-256$ & \\
\hline \multirow{6}{*}{$\begin{array}{c}\text { Гігромезофільна } \\
\text { липова діброва із } \\
\text { широкотрав'ям }\end{array}$} & зоофаги III порядку & 10,6 & 0,0 & 0,0 & 1063,2 & 1073,8 \\
\hline & зоофаги II порядку & 0,5 & 114,2 & 0,0 & 0,0 & 114,7 \\
\hline & зоофаги I порядку & 20,5 & 0,0 & 0,0 & 0,0 & 20,5 \\
\hline & сапрофаги & 0,0 & 26,3 & 0,0 & 1926,0 & 1952,3 \\
\hline & фітофаги & 3,7 & 87,3 & 111,0 & 0,0 & 202,0 \\
\hline & paзом & 35,3 & 227,8 & 111,0 & 2989,2 & 3363,3 \\
\hline \multirow{6}{*}{$\begin{array}{c}\text { Мезогігрофільна } \\
\text { діброва } \\
\text { з конвалією }\end{array}$} & зоофаги III порядку & 3,0 & 0,0 & 0,0 & 105,1 & 108,1 \\
\hline & зоофаги II порядку & 0,0 & 21,8 & 23,4 & 0,0 & 45,2 \\
\hline & зоофаги I порядку & 21,0 & 0,0 & 0,0 & 0,0 & 21,0 \\
\hline & сапрофаги & 0,0 & 96,9 & 0,0 & 0,0 & 96,9 \\
\hline & фітофаги & 3,4 & 0,0 & 60,6 & 0,0 & 64,0 \\
\hline & разом & 27,4 & 118,7 & 84,0 & 105,1 & 335,2 \\
\hline \multirow{6}{*}{$\begin{array}{c}\text { Мезогігрофільна } \\
\text { липо-ясенева } \\
\text { діброва із } \\
\text { широкотрав'ям }\end{array}$} & зоофаги III порядку & 6,1 & 0,0 & 0,0 & 0,0 & 6,1 \\
\hline & зоофаги II порядку & 0,0 & 17,6 & 0,0 & 0,0 & 17,6 \\
\hline & зоофаги I порядку & 15,7 & 12,2 & 0,0 & 0,0 & 27,9 \\
\hline & сапрофаги & 0,0 & 28,5 & 1914,0 & 2178,0 & 4120,5 \\
\hline & фітофаги & 0,0 & 20,5 & 90,8 & 78,8 & 190,1 \\
\hline & разом & 21,8 & 78,8 & 2004,8 & 2256,8 & 4362,2 \\
\hline \multirow{6}{*}{$\begin{array}{c}\text { Мезогігрофільна } \\
\text { в'язо-ясенева } \\
\text { діброва із } \\
\text { широкотрав'ям }\end{array}$} & зоофаги III порядку & 0,8 & 0,0 & 113,6 & 89,6 & 204,0 \\
\hline & зоофаги II порядку & 3,4 & 0,0 & 38,0 & 0,0 & 41,4 \\
\hline & зоофаги I порядку & 15,1 & 42,0 & 0,0 & 0,0 & 57,1 \\
\hline & сапрофаги & 0,0 & 28,5 & 290,0 & 0,0 & 318,5 \\
\hline & фітофаги & 8,1 & 17,5 & 0,0 & 77,0 & 102,6 \\
\hline & $\begin{array}{r}\text { paзом } \\
\end{array}$ & 27,4 & 88,0 & 441,6 & 166,6 & 723,6 \\
\hline
\end{tabular}

На відміну від попередньої пробної площі у мезогігрофільній діброві з конвалією (див. рис. 2, табл.) зафіксовано найнижчу біомасу безхребетних $\left(335,5 \mathrm{M \Gamma} / \mathrm{m}^{2}\right)$ серед обстежених пробних ділянок. На першому трофічному рівні згруповано 48,0 \% загальної біомаси; 3 них 28,9\% припадає на сапрофагів (Porcellio scaber Latreille, 1804, Julus terrestris Linnaeus, 1758), 19,1 \% - на фітофагів. Біомаса зоофагів I порядку дорівнює $6,3 \%$ біомаси мезофауни. Вага тварин, що увійшли до наступного трофічного рівня, дорівнює 13,5 \% відповідно. Найвищий трофічний рівень безхребетних тварин, який включає пантофагів і зоофагів ІІІ порядку, відрізняється від попередніх двох максимальною біомасою (32,2\%), головним чином через присутність Carabus granulatus Linnaeus, 1758.

Мезогігрофільна липо-ясенева діброва із широкотрав'ям характеризується найбільшою біомасою серед досліджених типів лісу (див. рис. 3, табл.). Біомаса мезофауни цієї пробної ділянки розподілена таким чином. Перший трофічний рівень становить $98,8 \%$ (сапрофаги - 94,5\%, фітофаги - 4,4\%); другий $(0,7 \%)$, третій $(0,4 \%)$ і четвертий $(0,1 \%)$ трофічні рівні разом не перевищують 1,5 \% сумарної ваги підстилкової мезофани. Привертає увагу той факт, що серед обстежених типів лісу на вищому (четвертому) трофічному рівні цього біогеоценозу не зустрічаються зоофаги III порядку. 


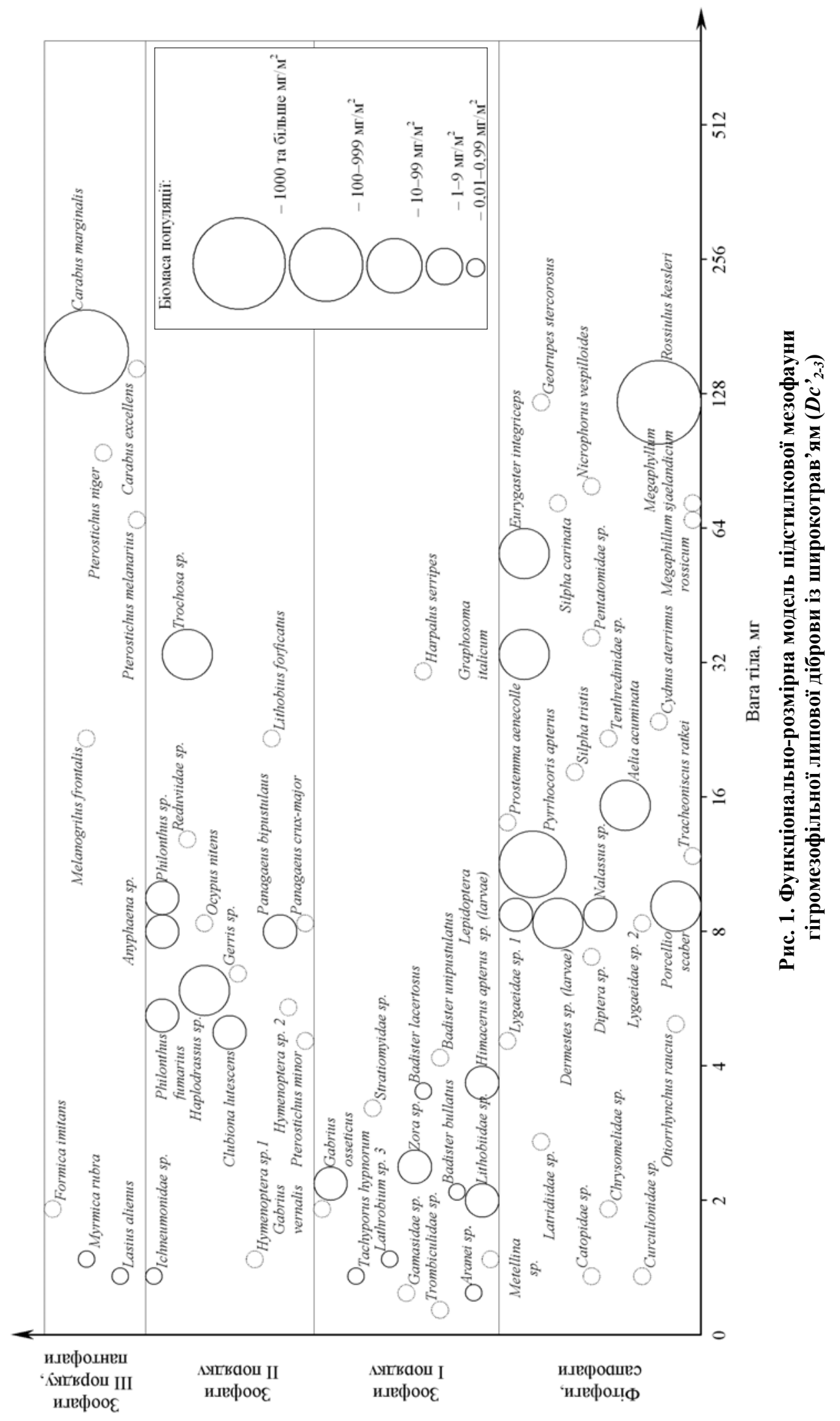




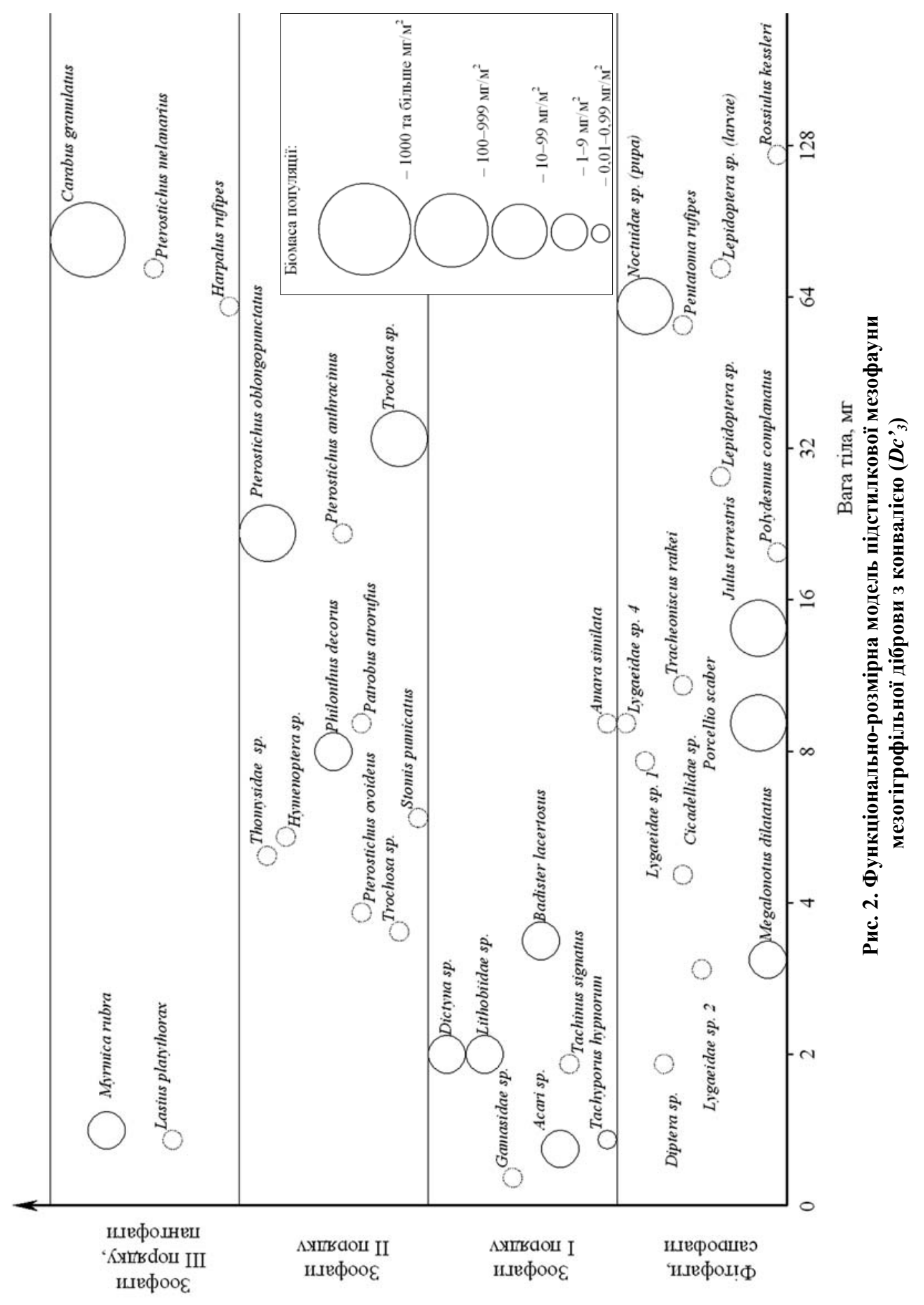




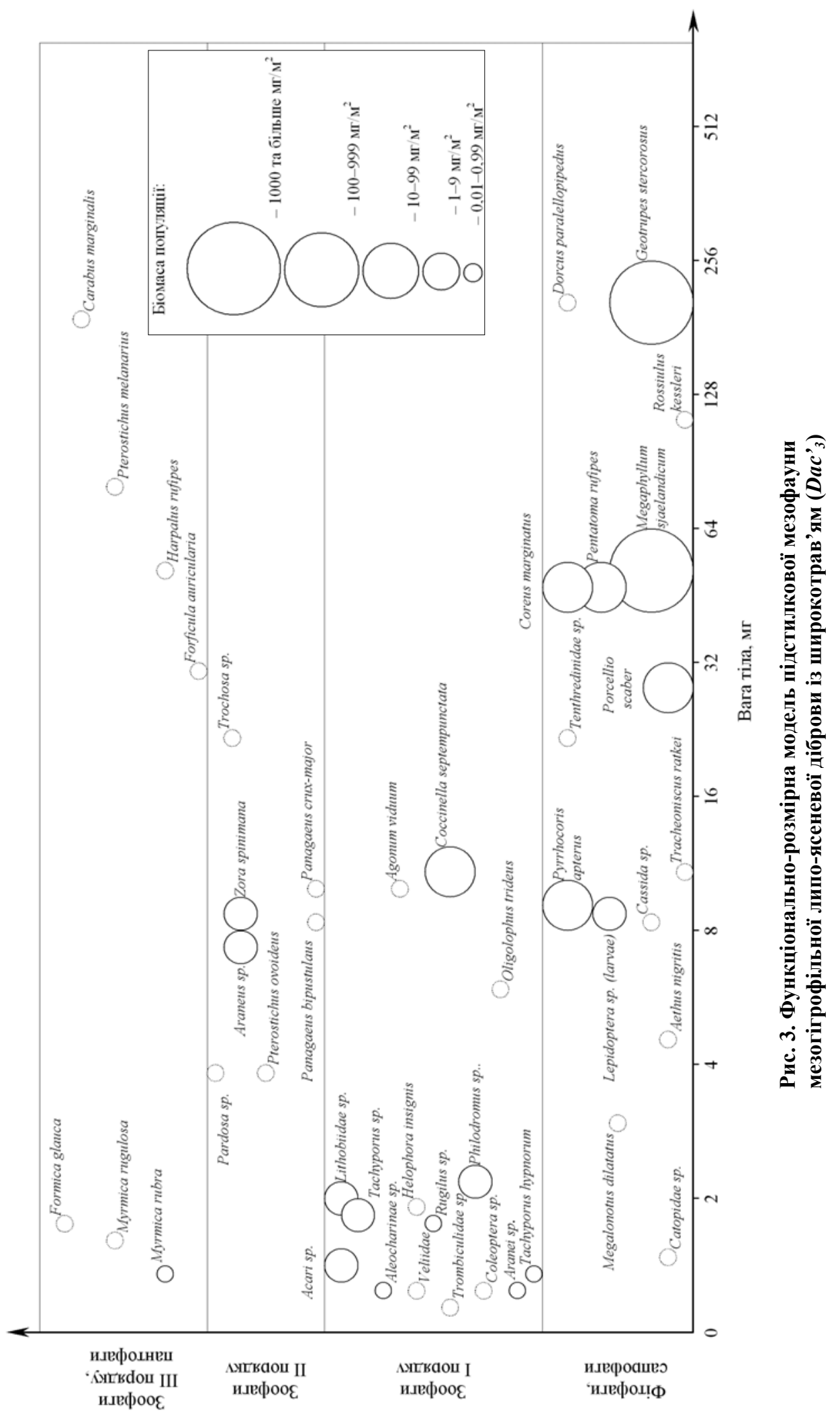




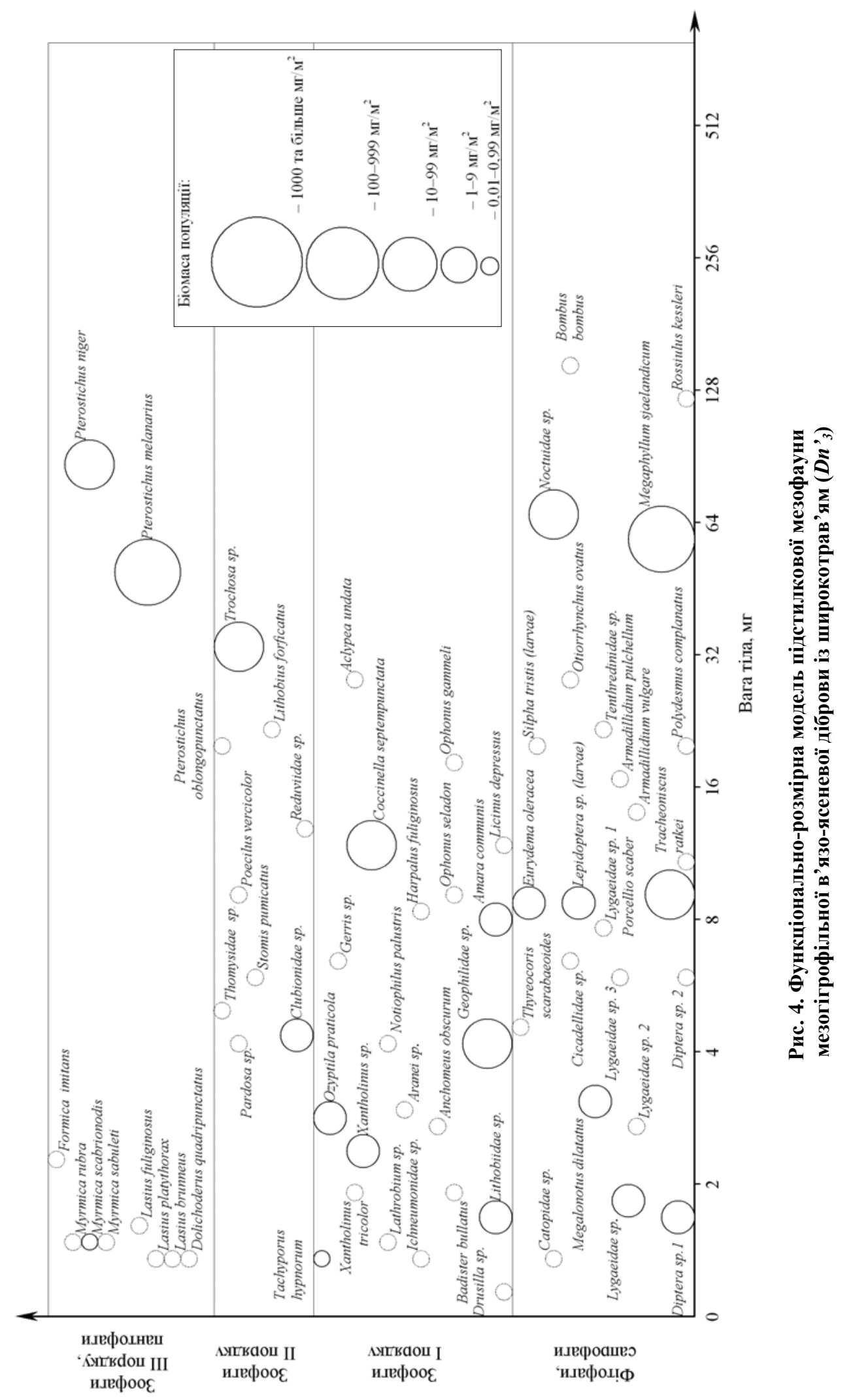


Цей лісовий біогеоценоз майже ідеально віддзеркалює теоретичний розподіл за біомасою між окремими трофічними рівнями [18; 25]. Проте біомаси угруповань можуть не корелювати з інтенсивністю потоків енергії, що проходять крізь трофічний рівень. За умов філогенетичної (а тому, вірогідно, й фізіологічної) близькості за тривалістю генерації біомаса популяцій може корелювати з потоком енергії, що через неї проходить. Серед сапрофагів домінують Geotrupes stercorosus (Scriba, 1791) та Megaphyllum sjaelandicum (Meinert, 1868).

У мезогігрофільній в'язо-ясеневій діброві із широкотрав'ям зібрано комах за-

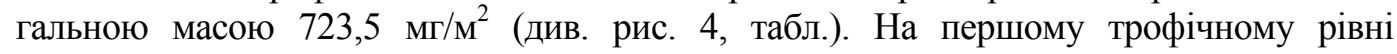
зосереджені безхребетні, що домінують на цій пробній ділянці $(58,2 \%$ загальної біомаси, при цьому біомаса сапрофагів становить 44,0 \%, а фітофагів - 14,2 \%). Другий трофічний рівень становить $7,9 \%$ біомаси мезофауни, третій $-5,7 \%$, четвертий 28,8 \%як бачимо, зі зростанням трофічного рівня у зоофагів найчастіше збільшуються розміри тіла. Виняток становлять види із соціальним способом життя (у помірній кліматичній зоні - перетинчастокрилі, наприклад мурахи, а в тропічних широтах - також інші ряди комах).

Необхідно зупинити увагу також на тому, що застосованим методом (ручне розбирання підстилки у польових умовах) важко виявити дрібних тварин вагою менше 0,5 мг. Саме цим пояснюється їх відсутність або мала кількість у моделі. Проте при розумінні функціональної активності герпетобію неможливо не брати до уваги присутність інших розмірних груп тварин (зокрема нано- та мікрофауни), які, без сумніву, відіграють важливу роль у встановленні ланцюгів живлення у природних екосистемах.

Треба підкреслити, що у даній роботі розглянуто лише фауну підстилкового біогеогоризонту, причому масу хребетних тварин не враховано. Тому у досліджених екосистемах відсутній класичний розподіл за біомасою (маса організмів трофічного рівня повинна становити $10 \%$ від біомаси популяцій, розташованих на один рівень нижче у трофічній піраміді) [18; 25]. До того ж, у лісових біогеоценозах спостерігається досить нерівномірний вертикальний розподіл окремих функціональних груп: максимальна частка фітофагів представлена мешканцями крон дерев і чагарників, грунтовими формами; сапрофаги домінують у грунті та підстилці; зоофаги різних порядків у геобії, герпетобії та хортобії розміщені досить рівномірно, їх максимальна біомаса зосереджена також у підстилці.

Таким чином, класичне графічне подання консорції [17] у вигляді системи кіл, у центрі якої схематично розташована окрема особина або популяція автотрофного організму, а навколо зосереджені кола однакового діаметра (які відображають наявність виду консумента певного порядку у складі консорції), порівняно із запропонованою нами формою, містить набагато менше інформації. У ній відсутні параметри розмірів тіла особин певного виду та сумарної біомаси його популяції.

Наведення при графічному відображенні у моделі кола, діаметр якого пов'язаний із логарифмом біомаси, дозволяе нівелювати розбіжності між біомасами популяцій, які часто досягають трьох-чотирьох порядків. Наведення у моделі одночасно результатів збирання безхребетних тварин із використанням грунтових пасток і ручного розбирання підстилки підвищує інформаційну ємність моделі.

\section{Висновки}

Підстилкова фауна різних типів заплавних дібров лісостепової зони має риси подібності, проте не позбавлена і відмінностей. Максимальні кількість видів і сумарна біомаса герпетобію зареєстровані в гігромезофільній липовій діброві із широко- 
трав'ям, мінімальні - у мезогігрофільній діброві з конвалією. Розгляд трофічної структури підстилкової мезофауни окремо від аналізу розмірно-вагової структури угруповання зумовлює втрату значної кількості інформації про зв'язки між елементами зооценозу. Запропонована модель наочно відображає кількісний і функціональний склад мезофауни лісового біогеоценозу, полегшує розуміння розподілу безхребетних за трофічними рівнями. Застосування цієї моделі дозволяє порівнювати різні типи лісу, а результати досліджень можуть використовуватися при здійсненні моніторингу обстежених екосистем.

\section{Бібліографічні посилання}

1. Беклемишев В. Н. Суточные миграции беспозвоночных в комплексе наземных биоценозов // Труды Пермского биологического НИИ при Пермском университете. - 1934. - Т. 6, вып. 3-4. C. $119-208$.

2. Беклемишев В. Н. О классификации биоценологических (симфизиологических) связей // Бюлл. МОИП. Отд. биол. - 1951. - Т. 56, № 5. - С. 3-30.

3. Бельгард А. Л. Степное лесоведение. - М.: Лесная промышленность, 1971. - 336 с.

4. Бригадиренко В. В. Пространственно-функционально-размерные модели в изучении сообществ почвенных и наземных беспозвоночных // Тези VI з'їзду Укр. ентомолог. т-ва. - Біла Церква: УЕТ, 2003. - С. 15-16.

5. Бригадиренко В. В. Система трофоконсортивних зв'язків підстилкових безхребетних заплавних дібров степової зони України / В. В. Бригадиренко, В. О. Слинько // Науковий вісник Чернівецького ун-ту. - 2005. - Вип. 257. - С. 42-50.

6. Булахов В. Л. Земноводные и пресмыкающиеся и их роль в жизни степных лесов / В. Л. Булахов, Ю. П. Бобылев, Н. Ф. Константинова // Вопросы степного лесоведения и охраны природы. - Д.: ДГУ, 1977. - Вып. 8. - С. 124-130.

7. Булахов В. Л. Функциональная роль высших гетеротрофов в становлении и эволюции лесных экосистем // Экология и ноосферология. - 1999. - Т. 6, № 1-2. - С. 145-150.

8. Булахов В. Л. Трофическая роль млекопитающих-фитофагов в лесньх биогеоценозах степного Приднепровья // Вестник Днепропетр. ун-та. Биология. Экология. - 2003. - Вып. 11, т. 1. C. $138-142$.

9. Быков Б. А. Введение в фитоценологию. - Алма-Ата: Наука КазССР, 1970. - 234 с.

10. Василевич В. И. Очерки теоретической фитоценологии. - Л.: Наука, 1983. - 248 с.

11. Гиляров М. С. Зоологический метод диагностики почв. - М.: Наука, 1965. -278 с.

12. Дылис Л. Г. Основы биогеоценологии. - М.: МГУ, 1977. -237 с.

13. Емельянов И. Г. Роль разнообразия в функциональной устойчивости экосистем // Экология и ноосферология. - 1999. - Т. 6, № 1-2. - С. 32-38.

14. Зонн С. В. Влияние леса на почвы. - М.: Наука, 1954. - 144 с.

15. Комаров О. С. Особливості формування фауни підстилкових безхребетних аренних лісів ріки Дніпро в умовах Полтавської області / О. С. Комаров, В. В. Бригадиренко // Екологія та ноосферологія. - 2008. - Т. 19, № 1-2. - С. 59-68.

16. Комаров О. С. Аналіз структури підстилкової мезофауни лісових біогеоценозів Полтавської області / О. С. Комаров, В. В. Бригадиренко // Вісник Дніпропетр. ун-ту. Біологія. Екологія. 2008. - Вип. 16, т. 1. - С. $111-118$.

17. Мазинг В. В. Консорции как элементы функциональной структуры биогеоценозов // Бюлл. МОИП. Отд. биол. - 1966. - Т. 27, № 2. - С. 117-126.

18. Одум Ю. Экология. - Т. 2. - М.: Мир, 1986. - 367 с.

19. Работнов Т. А. О консорциях // Бюллетень МОИП. Отд. биол. - 1969. - Т. 74, № 4. - С. 109-116.

20. Работнов Т. А. Значение консортивных связей в определении взаимных отношений растений в фитоценозах // Бюллетень МОИП. Отд. биол. - 1970. - Т. 75, № 2. - С. 68-75.

21. Работнов Т. А. Некоторые вопросы изучения консорций // Журнал общей биологии. - 1973. T. 34, № 3. - C. 407-416. 
22. Работнов Т. А. Луговедение. - М.: МГУ, 1974. - 384 с.

23. Работнов Т. А. Еще раз о консорциях // Бюллетень МОИП. Отд. биол. - 1978. - Т. 83, № 2. C. 88-95.

24. Раменский Л. Г. О некоторых принципиальных положеннях современной геоботаники // Ботан. журн. - 1952. - Т. 37, № 2. - С. 181-201.

25. Риклефс Р. Основы общей экологии. - М.: Мир, 1979. - 418 с.

26. Роль почвенной фауны в индикации эдафотопов лесных биогеоценозов в степи / А. П. Травлеев, Л. Г. Апостолов, И. К. Булик, М. А. Шимкина // Биологическая диагностика почв. - М.: Наука, 1976. - С. 280-281.

27. Селиванов И. А. Некоторые вопросы учения о консорциях // Уч. зап. Пермск. пед. ин-та. 1974. - T. 133. - C. 5-14.

28. Сукачев В. Н. Основы лесной биогеоценологии. - М.: Наука, 1964. - 564 с.

29. Сукачев В. Н. Основные понятия о биогеоценозах и общее направление их изучения // Программа и методика биогеоценологических исследований. - М.: Наука, 1966. - С. 5-21.

30. Сукачев В. Н. Определение понятия «лесной биогеоценоз», его компоненты и основные свойства // Избранные труды. - Т. 1. - Л.: Наука, 1972. - С. 329-356.

31. Топчиев А. Г. Животное население мертвого покрова в искусственных лесах степной зоны Украины // Искусственные леса степной зоны Украины. - Харьков: Изд-во ХГУ, 1960. С. 341-367.

32. Топчиев А. Г. Фауна почвенных беспозвоночных животных и распределение их в искусственных лесах степной зоны УССР // Искусственные леса степной зоны Украины. - Харьков: Изд-во ХГУ, 1960. - С. 401-416.

33. Травлеев А. П. Некоторые черты разложения органического опада древесных пород и взаимодействие продуктов их разложения с почвой // Вопросы степного лесоведения. - Вып. 1. Д.: ДГУ, 1968. - С. 15-29.

34. Травлеев А. П. Лес и почва в условиях степи / А. П. Травлеев, Л. П. Травлеев. - Д.: ДГУ, 1988. -85 c.

35. Стриганова Б. Р. Питание почвенных сапрофагов. - М.: Наука, 1980. - 243 с.

36. Стриганова Б. Р. Исследование роли мокриц и дождевых червей в процессах гумификации разлагающейся древесины // Почвоведение. - 1968. - № 8. - С. 85-90.

37. Царик И. В. Накопление и разложение подстилки в биогеоценозах субальпийского пояса Карпат. Автореф. дис. ... канд. биол. наук. - Д.: ДНУ, 1977. - 30 с.

38. Чернов Ю. И. Наземная зоомасса и некоторые закономерности ее зонального распределения / Ю. И. Чернов, К. С. Ходашова, Р. И. Злотин // Журнал общей биологии. - 1967. - Т. 28, № 2. С. 188-197.

39. Чернова Н. М. Экологические сукцессии при разложении растительных остатков. - М.: Наука, 1977. - 200 c.

40. Чорнобай Ю. М. Трансформація рослинного детриту в природних екосистемах. - Львів: ДПМ НАН України, 2000. - 352 с.

Надійшла до редколегії 21.04.2008 